\title{
KARAKTERISTIK KARSINOMA SEL SKUAMOSA RONGGA MULUT
}

\author{
*Rehulina Ginting, **Betty, ***Michelle \\ *Departemen Biologi Oral Fakultas Kedokteran Gigi Universitas Sumatera Utara \\ **Departemen Patologi Anatomi Fakultas Kedokteran Universitas Sumatera Utara \\ Jl. Alumni No.2 Kampus USU Medan \\ Telp. 0618216131 Fax. 0618213421
}

\begin{abstract}
Abstrak
Karsinoma sel skuamosa (KSS) adalah tumor ganas yang berasal dari sel epitel skuamosa dan merupakan salah satu jenis kanker ditemukan pada mukosa rongga mulut. Insidensi KSS sekitar 90\% dari seluruh jenis keganasan yang terdapat pada rongga mulut dan frekuensi KSS rongga mulut di Indonesia mencapai 3-5\% dari seluruh kanker organ tubuh lainnya. KSS dapat diklasifikasi berdasarkan morfologi karakteristik jaringannya, dimana dibagi kepada tiga jenis yaitu KSS berdiferensiasi baik, sedang dan buruk. Tujuan penelitian ini adalah untuk melihat karakteristik morfologi KSS rongga mulut berdasarkan jenis diferensiasinya. Rancangan penelitian ini merupakan deskriptif dengan cara cross sectional terhadap 30 sampel blok parafin yang terdiagnosa sebagai KSS rongga mulut yang diperoleh dari Laboratorium Patologi Anatomi FK USU/RSUP Haji Adam Malik Medan tahun 2009-2013, dan dilakukan pewarnaan Hematoxylin-Eosin (HE). Preparat diamati di bawah mikroskop cahaya Olympus CX21. Hasil penelitian menunjukkan KSS berdiferensiasi baik (63\%), KSS berdiferensiasi sedang (37\%), dan tidak ditemukan KSS berdiferensiasi buruk. Kesimpulan penelitian ini menunjukkan KSS berdiferensiasi baik lebih banyak dibandingkan KSS berdiferensiasi sedang, dan tidak ditemukan KSS berdiferensiasi buruk.
\end{abstract}

Kata kunci : karsinoma sel skuamosa rongga mulut, diferensiasi KSS

\section{PENDAHULUAN}

Lapisan rongga mulut terdiri dari epitel skuamosa berlapis pada permukaannya, dengan lapisan subepitel dibawahnya berupa jaringan ikat. Kebanyakan keganasan pada rongga mulut berasal dari permukaan epitel dan salah satunya adalah karsinoma sel skuamosa (KSS). ${ }^{1,2}$

KSS adalah suatu neoplasma invasif pada jaringan epitel rongga mulut dengan berbagai tingkat diferensiasi. KSS rongga mulut dapat terjadi pada semua tempat di rongga mulut, seperti pada bagian lidah, dasar mulut, palatum, mukosa pipi dan gingiva. KSS cenderung cepat bermetastase dan meluas. ${ }^{1,2}$ Insidensi KSS sekitar 90\% dari seluruh jenis keganasan yang terdapat pada rongga mulut, dan frekuensi KSS rongga mulut di Indonesia mencapai 3-5\% dari seluruh kanker organ tubuh lainnya. ${ }^{3}$

Penyebab KSS adalah multifaktorial yaitu tidak ada agen ataupun faktor (karsinogen) tunggal sebagai penyebab KSS yang telah ditegaskan atau diterima secara jelas. Terdapat dua faktor predisposisi terjadinya KSS, yaitu: (1). faktor intrinsik, seperti genetik; dan (2). faktor ekstrinsik, seperti menyirih, tembakau, alkohol, infeksi virus, malnutrisi dan trauma kronis. Proses terjadinya KSS adalah bertahap, akibat hilangnya pengontrolan terhadap siklus sel. ${ }^{1,4}$ Perubahan lesi normal menjadi karsinoma membutuhkan waktu yang lama, diamana adanya iritasi kronis dari bahan karsinogen terhadap sel epitel mengakibatkan proliferasi yang abnormal pada sel epitel tersebut. Inflamasi kronis dapat menyebabkan perubahan pada sel normal menjadi metaplasia, displasia, dan anaplasia (ini dikatagorikan sebagai karsinoma). ${ }^{4}$

Menurut kode morfologi dari International Classification of Diseases for Oncology (ICD-O) (821) dan Systematized Nomenclature of Medicine dimana jenisnya diberi kode $/ 0$ untuk tumor jinak, $/ 3$ untuk tumor ganas dan $/ 1$ untuk kasus borderline atau ragu-ragu. ${ }^{5} \mathrm{KSS}$ rongga mulut secara umum mempunyai gambaran histopatologi yang tidak berbeda dari KSS kulit maupun organ tubuh lainnya. KSS rongga mulut ada yang berdiferensiasi baik dimana menyerupai epitel skuamosa berlapis normal dan menghasilkan keratin dan ada juga KSS rongga mulut yang berdiferensiasi buruk. Berdasarkan derajat diferensiasi KSS rongga mulut, dapat dibagi kepada tiga, yaitu diferensiasi baik, sedang dan buruk., ${ }^{5,7}$

Pada praktek klinis, rencana pengobatan dan prognosis KSS rongga mulut terutama didasarkan pada tumor primer, metastasis kelenjar getah bening regional dan sistem pementasan metastasis $(T N M) .^{5}$ Namun, sistem ini tidak menyediakan informasi tentang karakteristik biologi dan tingkat keagresifan klinis tumor yang jelas, dan ini telah menimbulkan suatu sistem penilaian keganasan KSS rongga mulut yang multifaktorial dikembangkan. Sistem penilaian pertama 
KSS rongga mulut telah dikembangkan oleh Broder pada tahun 1927 dan yang baru-baru ini merupakan sistem penilaian Bryne (1989). Berdasarkan sistem penilaian Bryne, terdapat empat parameter yang diperlihatkan untuk menilai derajat diferensiasi KSS rongga mulut, yaitu derajat keratinisasi, pleomorphism inti, infiltrasi limfosit dan bentuk invasi tumor. Derajat diferensiasi KSS rongga mulut akan dinilai dengan memperhitungkan skor dari empat parameter tersebut, yaitu skor 4-8 (diferensiasi baik), skor 9-12 (diferensiasi sedang), dan skor 13-16 (diferensiasi buruk). ${ }^{6,7}$

Oleh karena itu, dalam penelitian ini akan dilihat jenis diferensiasi KSS berdasarkan karakteristik jaringan KSS rongga mulut dengan sistem penilaian Bryne.

\section{BAHAN DAN CARA}

Penelitian ini merupakan penelitian deskriptif dengan pendekatan cross-sectional. Besar sampel yang digunakan adalah 30 sampel blok parafin yang terdiagnosa sebagai KSS rongga mulut yang diperoleh dari Laboratorium Patologi Anatomi FK USU/RSUP Haji Adam Malik Medan tahun 2009-2013.

Blok parafin dilakukan processing laboratorium di laboratorium Patologi Anatomi Fakultas Kedokteran Universitas Sumatera Utara. Pewarnaan $H E$ dilakukan pada preparat yang tersedia dan pengamatan jaringan dengan menggunakan mikroskop cahaya Olympus CX21 dengan pembesaran 100x dan 400x.

\section{HASIL}

Dari hasil penilaian Bryne, ditemukan 19 sampel KSS rongga mulut masuk ke dalam skor 4-8, 11 sampel masuk ke dalam skor 9-12, dan tidak ditemukan sampel KSS rongga mulut yang masuk ke skor 13-16.

Tabel 1. Distribusi frekuensi KSS rongga mulut berdasarkan sistem penilaian Bryne.

\begin{tabular}{ll}
\hline \multicolumn{1}{c}{ Skor Bryne } & Sampel, $\boldsymbol{n}$ \\
\hline $4-8$ & 19 \\
$9-12$ & 11 \\
$13-16$ & 0 \\
\hline
\end{tabular}

Berdasarkan 30 sampel KSS rongga mulut yang diteliti dengan sistem penilaian Bryne, ditemukan KSS berdiferensiasi baik (63\%), KSS berdiferensiasi sedang (37\%), dan tidak ditemukan KSS berdiferensiasi buruk.

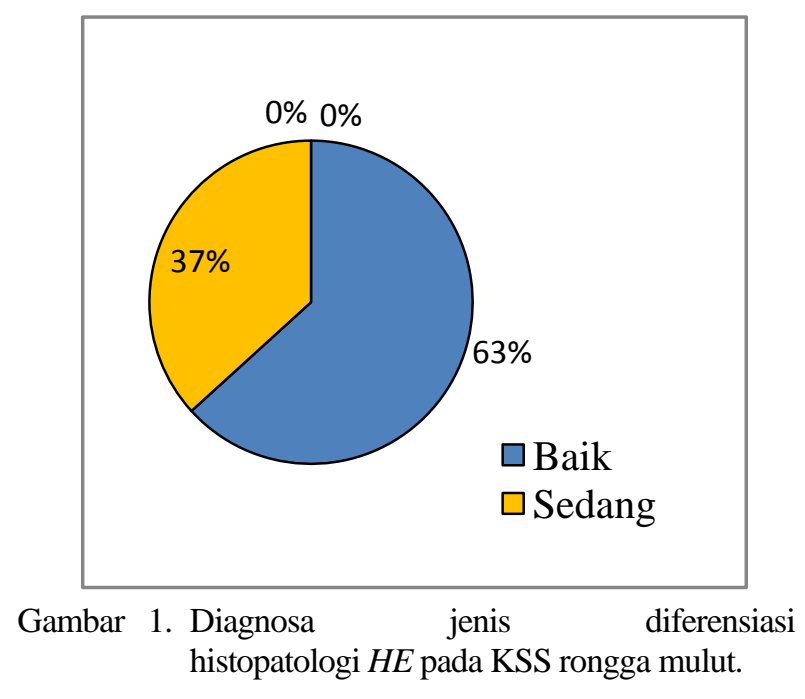

\section{PEMBAHASAN}

Pewarnaan Hematoxylin-Eosin (HE) adalah jenis pewarnaan rutin yang paling umum dipakai. Prosedur ini digunakan dalam proses pembuatan preparat histopatologi dari berbagai jenis jaringan yang memerlukan pemeriksaan atau peneguhan diagnosis yang bersangkutan. ${ }^{8}$

Derajat diferensiasi KSS rongga mulut dapat dibagi kepada tiga jenis, yaitu KSS berdiferensiasi baik, sedang, dan buruk. Penilaian derajat diferensiasi ini dapat berdasarkan sistem penilaian Bryne mengikut parameter morfologi skor masing-masing (Tabel 2). Parameter morfologi ini adalah adekuat dalam penilaian karakteristik jaringan KSS, dan merupakan suatu indikator dalam memprediksi prognosa KSS. ${ }^{6,7}$ Pada penelitian ini, KSS rongga mulut berdiferensiasi baik (63\%) lebih banyak ditemukan dibanding dengan KSS berdiferensiasi sedang (37\%), tetapi untuk KSS berdiferensiasi buruk tidak ditemukan (Gambar 1). Hasil derajat diferensiasi KSS yang diperoleh adalah berdasarkan jumlah hitungan skor parameter morfologi (Tabel 1), dimana skor 4-8 (diferensiasi baik), skor 9-12 (diferensiasi sedang), dan skor 13-16 (diferensiasi buruk). Menurut karakteristik morfologi KSS pada penelitian ini, skor 4-8 ditemukan mayoritas sampel mempunyai jaringan yang $>50 \%$ berkeratinisasi dan sel limfoplasmasistik yang banyak. Bagi skor 9-12, sampel jaringan ditemukan mempunyai keratinisasi $<50 \%$ atau tidak ada, bentuk inti beragam, dan mempunyai sel limfoplasmasistik yang kurang.

Tabel 2. Sistem penilaian derajat diferensiasi KSS rongga mulut dengan parameter Bryne. ${ }^{6}$

\begin{tabular}{|c|c|c|c|c|}
\hline \multirow{2}{*}{$\begin{array}{l}\text { Parameter } \\
\text { morfologi }\end{array}$} & \multicolumn{4}{|c|}{ Skor } \\
\hline & 1 & 2 & 3 & 4 \\
\hline $\begin{array}{l}\text { Derajat } \\
\text { keratinisasi }\end{array}$ & $\begin{array}{l}\quad>50 \% \\
\text { berkerati- } \\
\text { nisasi }\end{array}$ & $\begin{array}{l}20-50 \% \\
\text { berkerati- } \\
\text { nisasi }\end{array}$ & $\begin{array}{l}5-20 \% \\
\text { berkerati- } \\
\text { nisasi }\end{array}$ & $\begin{array}{l}\text { } 0-5 \% \\
\text { berkerati- } \\
\text { nisasi }\end{array}$ \\
\hline $\begin{array}{l}\text { Pleomorphis- } \\
\text { me inti }\end{array}$ & Sedikit & Sedang & Banyak & Sangat banyak \\
\hline Bentuk invasi & $\begin{array}{l}\text { Mendo- } \\
\text { rong, } \\
\text { berbatas } \\
\text { tegas }\end{array}$ & $\begin{array}{l}\text { Berinfil- } \\
\text { trasi, bentuk } \\
\text { benang } \\
\text { padat }\end{array}$ & $\begin{array}{l}\text { Kumpulan } \\
\text { sel-sel kecil } \\
\text { yang } \\
\text { berinfiltrasi }\end{array}$ & $\begin{array}{l}\text { Kumpulan sel- } \\
\text { sel kecil } \\
\text { tersebar luas } \\
\text { dan berinfil- } \\
\text { trasi }\end{array}$ \\
\hline $\begin{array}{l}\text { Infiltrasi } \\
\text { limfoplas- } \\
\text { masistik }\end{array}$ & Berat & Sedang & Ringan & Tidak ada \\
\hline
\end{tabular}


Keratin jenis hiperkeratotik yang ditemukan pada epitel dari sel tumor merupakan salah satu penanda untuk transformasi "maglinant" atau kanker. ${ }^{9} \mathrm{KSS}$ berdiferensiasi baik (Gambar 2) selalunya menunjukkan keratinisasi yang lebih banyak dibandingkan dengan KSS berdiferensiasi sedang dan buruk. KSS berdiferensiasi buruk mayoritas jaringannya tidak berkeratinisasi. KSS berdiferensiasi baik mempunyai sel yang mirip sel matur normal asal jaringan dan mempunyai sel limfosistik yang banyak akibat reaksi dari jaringan untuk memperbaiki sel yang rusak. KSS yang berdiferensiasi sedang (Gambar 3) dan buruk mempunyai sel atau inti yang pleomorfik, yaitu ukuran sel yang bervariasi dan besar, serta sering tidak ditemukan sel limfosistik. Pada KSS berdiferensiasi buruk (Gambar 4), adanya ditemukan sel kecil primitif, dimana sel asal jaringannya sulit dikenal $l^{7,9,10}$
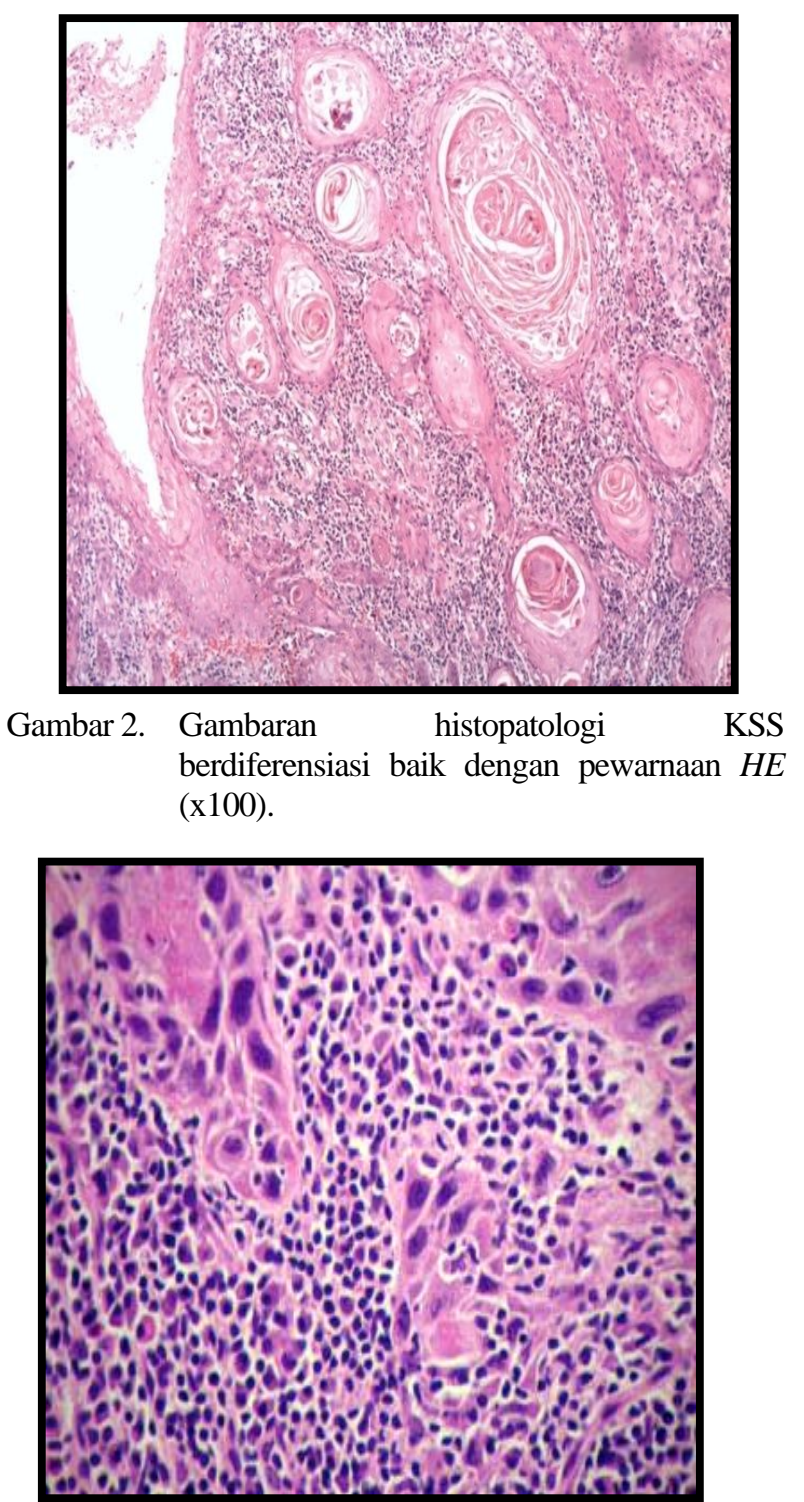

Gambar 3. Gambaran histopatologi KSS berdiferensiasi sedang dengan pewarnaan $H E$ (x400).

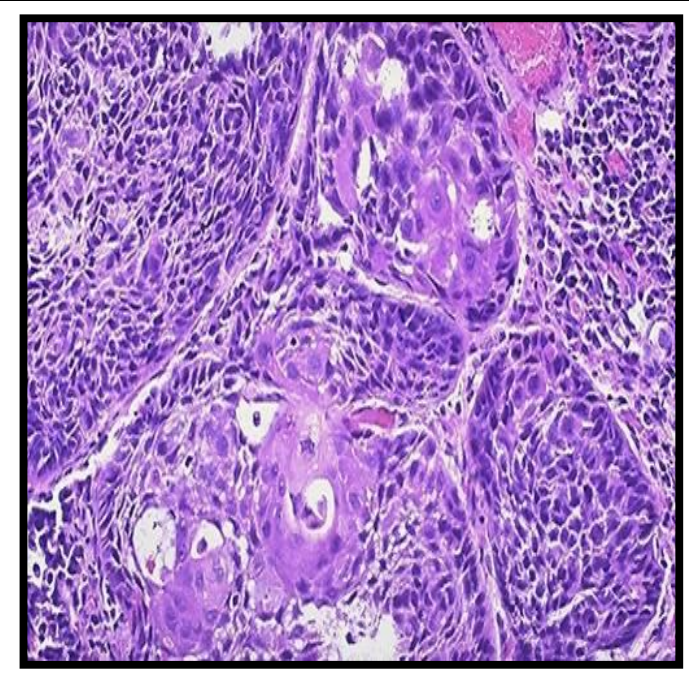

Gambar 4. Gambaran histopatologi KSS berdiferensiasi buruk dengan pewarnaan $H E$ (x400).

\section{KESIMPULAN}

Pada penelitian ini ditemukan KSS berdiferensiasi baik (63\%) dengan skor Bryne 4-8, KSS berdiferensiasi sedang (37\%) dengan skor Bryne 9-12, dan tidak ditemukan KSS berdiferensiasi buruk.

\section{DAFTAR PUSTAKA}

Cawson R, Odell E. Cawson's essential of oral pathology and oral medicine. $8^{\text {th }}$ ed. Toronto: Churchill Livingstone Elsevier; 2008. 277-83.

Epstein J. Burket's oral medicine diagnosis and treatment: Oral cancer. $10^{\text {th }}$ ed. Spain: BC Decker Inc; 2003. 195-9.

Syafriadi M. Pathogenesis of oral cancer. Indonesia Journal of Dentistry. 2008; 15(2): 104-10.

Williams HK. Molecular pathogenesis of oral squamous carcinoma. J of Clin Path. 2000; 53(4): 165-72.

Barnes L, Eveson JW, Reichart P, Sidransky D. World Health Organization classification of tumours. Pathology and genetics of head and neck tumours. IARC Press: Lyon 2005. 163-72.

Neena D, Siddharth S, Keyuri P, Munira J. Histological grading of oral cancer: a comparison of different systems and their relation to lymph node metastasis. National J of Community Med. 2011; 2(1): 136.

Bhargaca A, Saigal S, Chalishazar M. Histopathological grading systems in oral squamous cell carcinoma: A review. J Int Oral Health. 2010; 2(4): 1-10.

Kiernan JA. Histological and histochemical methods: Theory and practice. $4^{\text {th }}$ ed. Bloxham, UK: Scion; 2008.

Karantza V. Keratins in health and cancer: more than mere epithelial cell markers. J Oncology. 2011; 30(2): 127-38.

Pereira MC, Oliveira DT, Landman G, Kowalski LP. Histologic subtypes of oral squamous cell carcinoma: prognostic relevance. JCDA. 2007; 73(4): 339-40. 